\title{
HIF1 $\alpha$ Genetic Variants and Protein Expressions Determine the Response to Platinum Based Chemotherapy and Clinical Outcome in Patients with Advanced NSCLC
}

\author{
Fenglei Wu ${ }^{\mathrm{a}, \mathrm{c}}$ Jian Zhang ${ }^{\mathrm{b}, \mathrm{c}} \quad$ Yi Liu ${ }^{\mathrm{a}}$ Yigong Zheng ${ }^{\mathrm{a}} \quad \mathrm{Nan} \mathrm{Hu}^{\mathrm{a}}$ \\ aDepartment of Oncology, First People Hospital of Lianyungang, Lianyungang, ${ }^{\mathrm{b}}$ Department of General \\ Surgery, Huai'an First People's Hospital, Nanjing Medical University, Huai'an, P.R. China; 'Contributed \\ equally to this manuscript
}

\section{Key Words}

Hypoxia-inducible factor- $1 \alpha \cdot$ Chemotherapy $\bullet$ Non-small cell lung cancer $\bullet$ Prognosis

\begin{abstract}
Aim: To investigate whether the hypoxia-inducible factor- $1 \alpha$ (HIF-1 $\alpha$ ) genetic variants and protein expression affect the chemotherapy response and the clinical outcome of patients with advanced non-small cell lung cancer (NSCLC). Methods: A total of 741 patients with histologically confirmed advanced NSCLC were recruited. Two polymorphisms of HIF-1 $\alpha$ gene, namely, the C1772T (P582S) and G1790A (A588T) polymorphisms were determined. The HIF-1 $\alpha$ protein expression was determined in 162 different biopsy samples by immunohistochemistry. Results: All patients received platinum-based chemotherapy, 311 were chemotherapy responders and 430 were non-responders. The 1772 CC genotype carriers had a higher chance to be chemotherapy responders compared with those carrying the TT genotype. Patients with high HIF-1 $\alpha$ expressions had a significantly higher chance to be non-responder to chemotherapy than those with low HIF-1 $\alpha$ expressions. The patients with $1772 \mathrm{CC}$ had markedly longer overall survival (OS) and progression free survival (PFS) than those carrying the $1772 \mathrm{CT}$ and 1772TT genotype. The HIF-1 $\alpha$ expression level was significantly related to the OS, but not PFS. Conclusion: The results of our study suggest that HIF1 $\alpha$ genetic variants and protein expression may be used as marker to screen NSCLC patients who are more likely to be responder to platinum based chemotherapy.
\end{abstract}




\section{Introduction}

Non-small cell lung cancer (NSCLC) is the most common cause of cancer death worldwide. Epidemiological studies showed that more than 70\% of NSCLC patients have advanced disease at the time of diagnosis, leading to a poor prognosis [1,2]. Currently, Platinum based chemotherapy is the first line therapy for patients with inoperable advanced NSCLC; however, the response to chemotherapy varies significantly in these patients [1]. Although the application of many new regimens, the response rate to platinum chemotherapy remains only about $15 \%$ to $30 \%$ [2]. Many efforts have been done to explore the mechanism under which the NSCLC patient response differently to chemotherapy, which is important for individualized chemotherapy regime. Recent studies showed that the intrinsic factor, such as individual genetic background, is closely associated with the response to chemotherapy in patients receiving chemotherapy [2-4]. Several studies have reported the variants of some genes may be used as a molecular marker to predict the chemotherapy response in NSCLC patients [5-8]. But these reported predictors either have conflicting results, or the predictive efficacy was not sufficiently proved.

Hypoxia is regarded as a universal feature of solid tumors due to the imbalance between the consumption of oxygen by tumor tissue and the oxygen delivery from the supplying blood vessels [9]. Clinically, hypoxia is associated with resistance to anti-tumor treatments, especially radiation therapy, and is predictive of metastasis and poor outcome in a variety of tumor types [10-15]. Hypoxia-inducible factor-1 $\alpha$ (HIF-1 $\alpha$ ) is a key factor which regulates cellular response to hypoxia and its important role in the regulation of tumor biological behaviors by affecting angiogenesis, energy metabolism, vasomotor function and apoptotic/ proliferative activity has been documented previously [16-18]. Inhibition of HIF-1 $\alpha$ inhibits tumor growth, vascularization, invasion, metastasis, more interestingly, the resistance to radiation therapy and chemotherapy, consisting with the clinical finding which showed that HIF-1 $\alpha$ over-expression is associated with increased risk of patient mortality in many cancers [19-24]. HIF-1 $\alpha$ is regarded as a target for cancer chemotherapy, chemosensitization and chemoprevention $[25,26]$.

HIF-1 $\alpha$ expression is regulated by its gene polymorphism. Recently, two polymorphisms, namely, the C1772T (P582S) and G1790A (A588T) polymorphisms of the HIF-1 $\alpha$ gene have been reported to significantly increase gene transcriptional activity, leading to an increased expression of HIF-1 $\alpha$ mRNA and protein $[27,28]$.

To date, whether the HIF-1 $\alpha$ expression and its genetic variants influence on the chemotherapy response and clinical outcome of patients with NSCLC remains known. Based on the role of HIF- $1 \alpha$ in cancer cell biological behavior and clinical outcome after treatment, we assumed there might be an association between HIF-1 $\alpha$ genetic variants and chemotherapy response in NSCLC patients. In the present study, we enrolled NSCLC patients who underwent platinum-based chemotherapy to explore the association between the HIF$1 \alpha$ genetic variants, HIF-1 $\alpha$ protein expression and the chemotherapy response as well as the prognosis of NSCLC.

\section{Patients and Methods}

\section{Ethics statement}

The ethical committee of First People Hospital of Lianyungang approved the study (2004-No2). All participants provide their written informed consent to participate in this study.

\section{Patient enrollment}

A total of 741 patients with histologically confirmed stage III and IV NSCLC were consecutively recruited between July, 2007, and August, 2011. All the patients were enrolled according to the criteria described previously [29]. The staging system we used was the 7th edition of the TNM system [30]. Only patients with squamous cell carcinoma and adenocarcinoma were included in this study. The other exclusion 
criteria were as following: prior history of malignancy; previous chemotherapy, radiotherapy or surgery; chronic cardiovascular disorders and respiratory disorders which may affect the cardio-pulmonary function or oxygen metabolism (e.g. congestive heart failure, or recent myocardial infarction, chronic obstructive pulmonary disease, pulmonary hypertension, asthma, et al) ; congenital heart diseases; any severe mental disorder; infectious disease. The study was carried out with the approval of the Ethical Review Committee of the First People Hospital of Lianyungang (Approval No. 2007-A-3). The written informed consents were obtained from all patients enrolled in this study.

Before treatment, all the enrolled NSCLC patients underwent evaluation including medical history, complete physical examination, routine clinical biochemistry tests, chest computed tomography (CT) of the chest and abdomen. Demographic and clinical characteristics, including age, sex, smoking status, and tumor histology were also collected from clinical medical records with review by two oncologists blind to our study design. Subjects who had smoked less than one cigarette per day and in less than 1 year in their lifetime before enrollment were defined as non-smokers, otherwise were defined as smokers [31]. The overall survival (OS) and progression free survival (PFS) period were acquired by clinical medical records. OS was defined from the start date to receive chemotherapy to the last day of follow-up or death from any cause. PFS was calculated as the interval between the start date of chemotherapy and the date of confirmed cancer progression [29].

\section{Platinum-based chemotherapy}

The chemotherapeutic regimens were described previously [29]. All chemotherapy regents were administered intravenously, and all treatments were for two to six cycles. The responsiveness of patients to chemotherapy were determined=by the WHO criteria, namely, complete response (CR), partial response (PR), stable disease (SD), and progressive disease (PD). Patients with complete disappearance of all measurable lesions were defined as $\mathrm{CR}$, while those with at least $50 \%$ reduction in measurable lesions were defined as PR [32,33]. Patients with less than a 50\% decrease or no more than a $25 \%$ increase in the size of measurable lesions were defined as SD and those who have measurable lesions increased by more than $25 \%$ or new lesions were assigned as PD. For data analysis, CR and PR were combined as responders, and SD and PD were grouped as non-responders. The chemotherapy response was assessed by two independent oncologists who were unaware of our study protocol.

\section{HIF-1 $\alpha$ genotyping}

Genomic DNA was isolated from the peripheral blood leukocytes by using genomic DNA kit. The primer sequence for Polymerase chain reaction (PCR) were as following: 5'-CAT GTA TTT GCT GTT TTA AAG-3' forward primer and 5'-GAG TCT GCT GGA ATA CTG TAA CTG-3' reverse primer. PCR was performed to amplify the 178-bp fragment of the exon 12 of the HIF- $1 \alpha$ human gene. The mixture for PCR was in $30 \mu \mathrm{L}$, containing $200 \mathrm{ng}$ template DNA, $0.2 \mathrm{mM}$ of each dNTP, $0.5 \mu \mathrm{M}$ of each forward and reverse primer, $1.5 \mathrm{mM}$ $\mathrm{MgCl}_{2}, 0.5 \mathrm{U}$ of Taq polymerase and $3 \mu \mathrm{L}$ of $10 \mathrm{X}$ PCR buffer. The denaturation was at $95^{\circ} \mathrm{C}$ for $5 \mathrm{~min}$, followed by 35 cycles of denaturation at $95^{\circ} \mathrm{C}$ for $30 \mathrm{sec}$, annealing at $61^{\circ} \mathrm{C}$ for $30 \mathrm{sec}$, extension at $70^{\circ} \mathrm{C}$ for $1 \mathrm{~min}$, and a final extension at $72^{\circ} \mathrm{C}$ for $10 \mathrm{~min}$. PCR products were purified and sequenced using Big Dye Terminator kit (version 3.1) on an ABI Prism ${ }^{\circledR} 3100$ Automated DNA sequencer according to the manufacturer's protocol (Applied Biosystems, Foster City, CA) [34].

\section{Immunohistochemistry}

A total of 162 biopsy cancer samples were obtained from 162 studied participants. Frozen tissues were cut into $6 \mu \mathrm{m}$ serial sections, dried on a $50^{\circ} \mathrm{C}$ hot plate for $2 \mathrm{~min}$, and fixed in $4 \%$ formaldehyde in PBS (pH 7.4) for $10 \mathrm{~min}$. Anti-HIF1 $\alpha$ polyclonal antibody (Millipore Corporation ${ }^{\circledR}$, USA) was diluted at a 1:150 for immunohistochemistry reaction. Sample staining was scored by semi-quantitative microscopic analysis, considering the number of stained cells and signal intensity. According to the percentage of HIF1 $\alpha$ immunepositive tumor cells, a score of 1 was assigned when $\leq 10 \%$ of positive cells were positive; 2 when $10-50 \%$ of cells were positive and 3 when $\geq 50 \%$ of cells were positive. Signal intensity was evaluated as negative (0), weak (1), moderate (2) and strong (3). Both scores were multiplied to categorize HIF1 $\alpha$ expression as low $(0-6)$ and high (>6) expressions [35] . 


\begin{tabular}{|c|c|c|}
\hline Cellular Physiology & Cell Physiol Biochem 2013;32:1566-1576 & \\
\hline and Biochemistry & $\begin{array}{l}\text { DOI: } 10.1159 / 000356593 \\
\text { Published online: December 03, } 2013\end{array}$ & $\begin{array}{l}\text { O } 2013 \text { S. Karger AG, Basel } \\
\text { www.karger.com/cpb }\end{array}$ \\
\hline
\end{tabular}

Table 1. Patient characteristics between chemotherapy responder and non-responders

\begin{tabular}{|c|c|c|c|c|c|}
\hline Characteristics Patient & Responder & & Non-respon & & $\mathrm{P}$ \\
\hline Age (years) & $58.6 \pm 6.1$ & & $60.4 \pm 4.3$ & & 0.053 \\
\hline \multicolumn{6}{|l|}{ Gender } \\
\hline Male & 171 & $55 \%$ & 204 & $47.40 \%$ & \multirow[t]{2}{*}{0.281} \\
\hline Female & 140 & $45 \%$ & 226 & $52.60 \%$ & \\
\hline \multicolumn{6}{|l|}{ Smoke status } \\
\hline non-smokers & 144 & $46.30 \%$ & 167 & $38.80 \%$ & \multirow[t]{2}{*}{0.025} \\
\hline smoker & 167 & $53.70 \%$ & 263 & $61.20 \%$ & \\
\hline \multicolumn{6}{|l|}{ Histology } \\
\hline Squamous cell carcinoma & 100 & $32.20 \%$ & 123 & $28.60 \%$ & \multirow[t]{2}{*}{0.225} \\
\hline Adenocarcinoma & 211 & $67.80 \%$ & 307 & $71.40 \%$ & \\
\hline \multicolumn{6}{|l|}{ Stage } \\
\hline IIIA & 134 & $43.09 \%$ & 135 & $31.40 \%$ & \multirow[t]{3}{*}{0.002} \\
\hline IIIB & 100 & $32.15 \%$ & 148 & $34.42 \%$ & \\
\hline IV & 77 & $24.76 \%$ & 147 & $34.19 \%$ & \\
\hline \multicolumn{6}{|l|}{ Differentiation } \\
\hline Well & 117 & $37.74 \%$ & 133 & $30.93 \%$ & \multirow[t]{3}{*}{0.016} \\
\hline Moderate & 115 & $33.55 \%$ & 146 & $33.95 \%$ & \\
\hline Poor & 79 & $28.71 \%$ & 151 & $35.12 \%$ & \\
\hline \multicolumn{6}{|l|}{ Chemotherapy regimens } \\
\hline DDP/CBP+TAX/TXT/DOC & 132 & $42.44 \%$ & 155 & $36.05 \%$ & \multirow[t]{3}{*}{0.150} \\
\hline DDP/CBP+GEM & 101 & $32.48 \%$ & 166 & $38.60 \%$ & \\
\hline $\mathrm{DDP} / \mathrm{CBP}+\mathrm{NVB}$ & 78 & $25.08 \%$ & 109 & $25.35 \%$ & \\
\hline
\end{tabular}

Statistical Analysis

Data on quantitative characteristics are expressed as means \pm stand deviation (SD). Data on qualitative characteristics are shown as percent values or absolute numbers. Differences in demographic characteristics and cancer risk factors between patients and controls were compared by using Student's $t$ test or ANOVA for continuous variables and the $\chi 2$ test for all categorical variables. To estimate the deviation of frequency of gene alleles in tested population, we performed the Hardy-Weinberg equilibrium using $\chi 2$ tests. The correlations between immunohistochemical expression, patients or tumor characteristics, and response to chemotherapy were examined using the $\chi 2$ test (or Fisher's exact test, as appropriate). Multivariate logistic regression analysis was used to determine the influence of HIF-1a polymorphisms on the chemotherapy response, controlling potential confounding conventional risk factors. A forward stepwise (Likelihood Ratio) procedure was used for multivariable analysis. The Kaplan-Meier Method was used to calculate OS. The differences in OS were compared using log-rank test. The Cox proportional hazards model was used to calculate the prognostic values of the protein expression and other pretreatment factors including age, sex, histology, number of disease sites and presence of pleura effusion. Factors that showed significance in the univariate model were included in the multivariate analysis. Data were analyzed with the SAS 9.2 package (SAS INC. NC. USA).The results were considered statistically significant at $\mathrm{P}<0.01$ using a 2 -tailed test.

\section{Results}

All patients subject received platinum-based chemotherapy, 311 were chemotherapy responder (CR + PR) and 430 were non-responder (SD + PD). Non-responders had higher prevalence of smokers, patients with stage IV and with poor differentiation than responders (all $\mathrm{P}<0.05$, Table 1). There were no significant differences in sex, age, histology and chemotherapy regimens between responders and non-responders (all $\mathrm{P}>0.05$ ). 
Table 2. The genotype frequencies for HIF-1 $\alpha$ polymorphisms between responders and non-responders

\begin{tabular}{lcccccccc}
\hline & $\begin{array}{c}\text { responders } \\
\end{array}$ & N=311 & $\%$ & $\begin{array}{c}\text { non-responders } \\
\text { N=430 }\end{array}$ & $\%$ & adjusted OR & $95 \% \mathrm{CI}$ & $\begin{array}{c}\text { Adjusted } \\
\mathrm{P}\end{array}$ \\
\hline HIF-1 $\alpha$ & $\mathrm{N}$ & $\%$ & $\mathrm{~N}$ & $\%$ & & & & \\
1790GG & 85 & $27 \%$ & 119 & $28 \%$ & 1 & & & \\
1790GA & 146 & $47 \%$ & 206 & $48 \%$ & 0.99 & 0.70 & 1.41 & 0.97 \\
1790AA & 80 & $26 \%$ & 105 & $24 \%$ & 1.07 & 0.71 & 1.6 & 0.75 \\
$\mathrm{G}$ & 316 & $51 \%$ & 444 & $52 \%$ & 1 & & & \\
$\mathrm{~A}$ & 306 & $49 \%$ & 416 & $48 \%$ & 1.03 & 0.84 & 1.27 & 0.75 \\
$1772 \mathrm{TT}$ & 60 & $19 \%$ & 141 & $33 \%$ & 1 & & & \\
$1772 \mathrm{CT}$ & 145 & $47 \%$ & 199 & $46 \%$ & 1.71 & 1.18 & 2.48 & 0.004 \\
$1772 \mathrm{CC}$ & 106 & $34 \%$ & 90 & $21 \%$ & 2.77 & 1.83 & 4.18 & $<0.001$ \\
$\mathrm{~T}$ & 265 & $43 \%$ & 481 & $56 \%$ & 1 & & & \\
$\mathrm{C}$ & 357 & $57 \%$ & 379 & $44 \%$ & 1.71 & 1.39 & 2.11 & $<0.001$ \\
\hline
\end{tabular}

Fig. 1. The Typical HIF-1 $\alpha$ expression figures. Typical HIF-1 $\alpha$ expression in adenocarcinoma (A 1 and A2) and squamous cell carcinoma (B 1and B2). A1 and B1 samples were from non-responders while A2 and B2 samples were from responders.

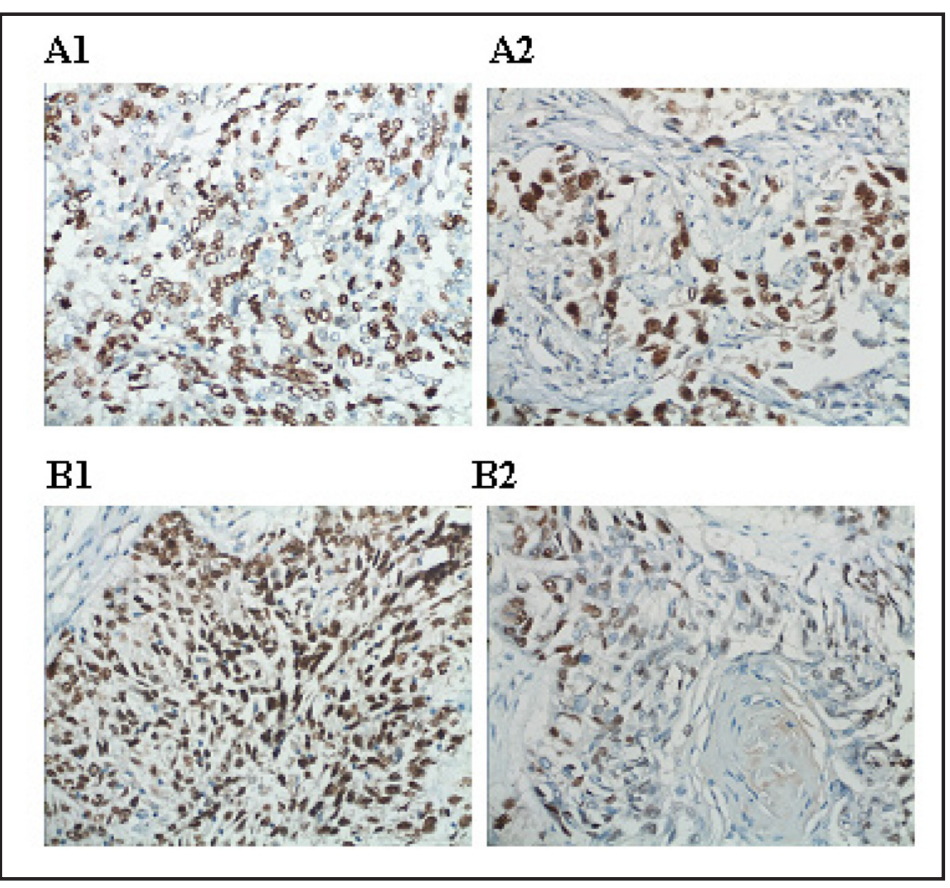

Genotype frequencies of HIF-1 $\alpha$ polymorphisms in chemotherapy responder and nonresponders were found to be fit in the Hardy-Weinberg equilibrium (all $\mathrm{P}>0.05$ ). Table 2 shows that the genotype and the allele frequencies of HIF-1 $\alpha$ polymorphism of $1790 \mathrm{G}>\mathrm{A}$ were not significantly different between responder and non-responders. However, the genotypes and allele frequency of HIF-1 $\alpha$ polymorphism of $1772 \mathrm{C}>\mathrm{T}$ were significantly different between the responders and non-responders. Responders had a markedly higher frequency of CC genotype than responders $(34 \%$ vs. $21 \%$, overall $\mathrm{P}<0.0012$, Table 2$)$. With TT as reference, multivariate logistic regression analysis showed the CC genotype carriers had a higher chance to be chemotherapy responders (adjusted OR=2.77, 95\% CI:1.83-4.18, adjusted $\mathrm{P}<0.001$, power value 0.96 ) with adjustment for age, sex, smoke status, histology, cancer stage and chemotherapy regime. The CT genotype carriers is also associated with the occurrence of chemotherapy resistance (adjusted OR=1.71, 95\% CI: 1.18-2.48, adjusted $\mathrm{P}=0.004$, power value 0.86 ). The $\mathrm{C}$ allele carriage represented a higher possibility to be responders to chemotherapy after adjustment with the above mentioned clinical variables 
Table 3. The HIF-1 $\alpha$ expression and response status in 162 patients

\begin{tabular}{ccccccccc}
\hline \multirow{2}{*}{ HIF-1 $\alpha$ expression } & \multicolumn{2}{c}{ non-responders } & \multicolumn{2}{c}{ responders } & adjusted OR & $95 \% \mathrm{CI}$ & adjusted P \\
& $\mathrm{N}$ & $\%$ & $\mathrm{~N}$ & $\%$ & & & & \\
& & & & & & & & \\
\hline Low & 40 & $38.10 \%$ & 36 & $63.16 \%$ & 1.00 & & & \\
High & 65 & $61.90 \%$ & 21 & $36.84 \%$ & 2.79 & 1.43 & 5.43 & $<0.001$ \\
\hline
\end{tabular}

Table 4. The associations between HIF-1 $\alpha$ polymorphisms and PFS and OS of NSCLC patients underwent chemotherapy

\begin{tabular}{|c|c|c|c|c|}
\hline $\begin{array}{c}\text { HIF- } 1 \alpha \\
\text { Polymorphisms }\end{array}$ & $\begin{array}{l}\text { Median PFS, mo } \\
\quad(95 \% \mathrm{CI})\end{array}$ & Log-rank P & $\begin{array}{c}\text { Median OS, } \\
\text { mo }(95 \% \mathrm{CI})\end{array}$ & Log-rank P \\
\hline \multicolumn{5}{|l|}{$1790 \mathrm{G}>\mathrm{A}$} \\
\hline $1790 \mathrm{GG}$ & $6.8(5.1-9.2)$ & 0.536 & $12.6(9.63-14.4)$ & 0.559 \\
\hline $1790 \mathrm{GA}$ & $6.6(5.2-10.1)$ & & $13.2(8.2-22.8)$ & \\
\hline $1790 \mathrm{AA}$ & $6.7(4.9-10.7)$ & & $12.9(8.6-21.3)$ & \\
\hline \multicolumn{5}{|l|}{$1772 \mathrm{~T}>\mathrm{C}$} \\
\hline $1772 \mathrm{TT}$ & $6.4(5.5-10.2)$ & 0.002 & $11.4(4.8-16.5)$ & 0.001 \\
\hline $1772 \mathrm{CT}$ & $6.7(4.7-11.1)$ & & $15.7(10.8-18.4)$ & \\
\hline $1772 \mathrm{CC}$ & $9.1(7.4-14.8)$ & & $19.5(12.1-22.8)$ & \\
\hline \multicolumn{5}{|l|}{ HIF- $1 \alpha$ expression } \\
\hline Low & $7.2(4.5-15.2)$ & 0.051 & $13.5(7.1-20.8)$ & $<0.001$ \\
\hline High & $6.9(4.4-11.8)$ & & $9.7(6.8-15.4)$ & \\
\hline \multicolumn{5}{|c|}{ Chemotherapy response } \\
\hline Yes & $10.4(7.5-24.2)$ & $<0.001$ & $18.5(11.1-28.8)$ & $<0.001$ \\
\hline No & $6.7(5.4-11.5)$ & & $9.9(5.8-14.2)$ & \\
\hline
\end{tabular}

(adjusted OR=1.71, 95\% CI: 1.39-2.11, $\mathrm{P}<0.001$, power value 0.99) compared with T allele carriage. However, multivariate logistic regression analysis did not reveal any association between HIF- $1 \alpha$ polymorphism at $1790 \mathrm{G}>\mathrm{A}$ and chemotherapy response in these patients (all $\mathrm{P}>0.05$, Table 2).

The HIF-1 $\alpha$ expression levels were determined by immuhistological staining. Of 162 biopsy sample donors, 57 were responders to chemotherapy while 105 were non-responders. The HIF- $1 \alpha$ high expressions were observed in 65 of non-responders $(61.90 \%)$ but only 21 in responders (36.84\%). The typical HIF-1 $\alpha$ expression in adenocarcinoma and squamous cell carcinoma samples are shown in Figure 1. Table 3 shows the distribution of HIF- $1 \alpha$ expression and response status. Patients with high HIF-1 $\alpha$ expression had a significantly higher risk to be non-responder to chemotherapy than those with low HIF-1 $\alpha$ expression (OR=2.79, 95\%CI: $1.43-5.43, \mathrm{P}<0.001$, power value 0.86 ).

The associations between the clinical characteristics and PFS as well as OS were studied by log-rank test (Table 4). For PFS, there were no significant differences in PFS with respect to HIF- $1 \alpha$ genotypes at $1790 \mathrm{G}>\mathrm{A}$ locus (both Log-rank $\mathrm{P}>0.05$ ). In contrast, the HIF- $1 \alpha$ gene $1772 \mathrm{C}>\mathrm{T}$ polymorphisms showed statistically significant associations with PFS and OS by 
Table 5. HR for prognosis of NSCLC patients underwent chemotherapy

\begin{tabular}{lccc}
\hline Factors & HR & $95 \%$ CI & P \\
\hline Chemotherapy response & 2.21 & $1.45-3.65$ & 0.003 \\
HIF-1 $\alpha$ expression & 3.25 & $2.14-4.11$ & $<0.001$ \\
HIF-1 $\alpha$ 1772T $>$ C & 2.64 & $1.83-4.27$ & 0.001 \\
\hline
\end{tabular}

Table 6. The association between HIF-1 $\alpha$ gene polymorphisms and HIF-1 $\alpha$ protein expression status

\begin{tabular}{lccccc}
\hline \multicolumn{5}{c}{ High expression } & \multicolumn{4}{c}{ Low expression } \\
\hline & $\mathrm{N}$ & $\%$ & $\mathrm{~N}$ & $\%$ & $\mathrm{P}$ \\
$1790 \mathrm{GG}$ & 21 & $28 \%$ & 20 & $23 \%$ & \\
$1790 \mathrm{GA}$ & 34 & $45 \%$ & 45 & $52 \%$ & \\
$1790 \mathrm{AA}$ & 21 & $28 \%$ & 21 & $24 \%$ & 0.624 \\
& & & & & \\
$1772 \mathrm{TT}$ & 14 & $18 \%$ & 23 & $27 \%$ & \\
$1772 \mathrm{CT}$ & 35 & $46 \%$ & 52 & $60 \%$ & \\
$1772 \mathrm{CC}$ & 27 & $36 \%$ & 11 & $13 \% 0.003$ \\
\hline
\end{tabular}

log-rank tests. The median survival time for patients with CC, CT and TT genotype carriers was shown in Table 4 (adjusted $\mathrm{P}=0.002$ for $\mathrm{PFS}$ and adjusted $\mathrm{P}=0.001$ for $\mathrm{OS}$ ). When stratified by HIF-1 $\alpha$ expression, we found that the HIF expression level significantly related to the OS, but not the PFS after adjustment with age, sex, smoke status, histology, cancer stage and chemotherapy regime (adjusted $\mathrm{P}=0.051$ for $\mathrm{PFS}$ and adjusted $\mathrm{P}<0.001$ for $\mathrm{OS}$ ). Patients with high HIF-1 $\alpha$ expression had similar FPS periods, but a significantly shorter OS period than those with low HIF expression. Chemotherapy response status also determined the PFS and OS periods (both adjusted $\mathrm{P}<0.001$ ).

We performed multivariate Cox proportional hazards regression models to estimate the hazard ratios (HR) for OS, with adjustment for age, sex, smoking status, histology, stage, chemotherapy regimes and response status. The risk factors influencing prognosis included $1772 \mathrm{~T}>\mathrm{C}$, HIF-1 $\alpha$ expression, chemotherapy response (Table 5).

Table 6 shows the association between HIF- $1 \alpha$ gene polymorphisms and HIF- $1 \alpha$ protein expression status in cancer tissues. We found that TT carriers had higher rate of patients with high HIF- $1 \alpha$ expression compared with CC carriers $(\mathrm{P}=0.003)$. The CC genotype carriers had a higher percentage of low HIF-1 $\alpha$ protein expression. In contrast, the 1790 $\mathrm{G}>\mathrm{A}$ polymorphisms was not related to HIF- $1 \alpha$ protein expression status.

\section{Discussion}

This is the first study presenting the positive association between the genetic variants and protein expression of an important hypoxia related protein, HIF- $1 \alpha$, with the response to Platinum based chemotherapy and clinical outcome in patients with advanced NSCLC. We found that the 1772 CC genotype carriers had a higher chance to be chemotherapy responders compared with those carried TT genotype. Patients with high HIF-1 $\alpha$ expression had a significantly higher chance to be non-responder to chemotherapy than those with 
low HIF expression. For prognosis analyses, we found that the HIF-1 $\alpha$ gene $1772 \mathrm{C}>\mathrm{T}$ polymorphisms showed statistically significant associations with PFS and OS by log-rank tests.

The patients with CC had markedly longer PFS and OS than those carrying CT and TT genotype. The HIF- $1 \alpha$ expression level significantly related to the OS, but not the FPS. Multivariate Cox proportional hazards regression models confirmed that the $1772 \mathrm{~T}>\mathrm{C}$ and HIF-1 $\alpha$ expression determined the prognosis of advanced NSCLC patients underwent thermotherapy.

The HIF-1 $\alpha$ gene is located at chromosome 14q21-q24.There are two important singlenucleotide polymorphisms (SNPs) of human HIF-1 gene, C1772T (P582S) and G1790A (A588T), which result in an amino acid substitution of proline to serine and alanine to threonine, respectively. Under normoxic condition, hydroxylation of the Pro402 and Pro564 occurs within the oxygen-dependent degradation domain of the HIF- $1 \alpha$, and HIF$1 \alpha$ will be rapidly degraded subsequently. The polymorphic S582 and T588 variants, with amino acid transition, may enhance the transcriptional activity of HIF- $1 \alpha$ gene because of structural changes. The polymorphisms at C1772T (P582S) and G1790A (A588T) of the HIF- $1 \alpha$ gene have been previously identified in esophageal squamous cell carcinomas, breast cancer, colorectal and prostate cancers and breast [27, 36-41]. The impact of HIF-1 $\alpha$ gene polymorphism and HIF mRNA and protein expression has been reported previously. HIF-1 $\alpha$ mRNA expression levels were significantly higher in prostate cancer patients with the TT genotype compared with the CC genotype. Expression of C1772T HIF-1 $\alpha$ in HIF- $1 \alpha$ knockout cancer cells showed higher expression levels and stabilization of HIF-1 $\alpha$ mRNA compared with the wild-type. Mutated HIF-1 $\alpha$ protein half-life was similar to that of the wild-type. These data provide evidence that C1772T polymorphism causes activation of HIF- $1 \alpha$ as a gain-of-function mechanism driven by stabilization of HIF- $1 \alpha$ mRNA [27]. In breast cancer, the frequency of the $\mathrm{T}$ allele of $\mathrm{C} 1772 \mathrm{~T}$ in breast cancer patients and healthy controls was similar, whereas, the frequency of the A allele for G1790A was significantly different. The HIF-1 $\alpha$ overexpression is associated with the T1772 polymorphic allele [42]. In our study, we used immunohistological staining to analyses the relation between the HIF$1 \alpha$ genotype and its protein expression level in NSCLC cancer tissues. We find that the TT carriers had higher rate of patients with high HIF-1 $\alpha$ expression compared with CC carriers; our results were consistent with the finding of XXX.

The association of HIF-1 $\alpha$ polymorphisms with susceptibility to non-small-cell lung cancer has been reported. In another Chinese population, the genotype frequencies of HIF$1 \alpha-1772 \mathrm{C} / \mathrm{T}$ and $-1790 \mathrm{G} / \mathrm{A}$ were found significantly different between NSCLC patients and the healthy controls. Logistic regression analysis revealed that subjects carrying the HIF$1 \alpha-1772 \mathrm{~T} / \mathrm{T}$ and $1790 \mathrm{~A} / \mathrm{A}$ genotypes had higher odds ratios for NSCLC than those who carrying the CC/CT genotypes and GG/GA genotypes [43].

Hypoxia frequently occurs in solid tumors and is known to contribute to chemotherapy resistance. In NSCLC cell lines, chronic moderate hypoxia induced resistance to cisplatin by inhibition of apoptosis, but largely independent from growth rate. Cisplatin resistance in NSCLC cell line is reversible after re-oxygenation and the stabilization of the HIF also plays an important role in this process [44]. HIF1 promoter activation can enhance Chemotherapeutic Sensitivity of Lung Cancer Cell Line AHIF1A. In this study, we provide evidence that the HIF$1 \alpha$ gene $1772 \mathrm{C}>\mathrm{T}$ polymorphisms were closely associated with the response to the platinum based thermotherapy in advanced NSCLC patients. Our result suggests that the detection of HIF-1 $\alpha$ genetic polymorphism may be used to screen those who are HIF- $1 \alpha$ sitive/resistive to thermotherapy in NSCLC cohort.

The prognostic role of HIF- $1 \alpha$ gene $1772 \mathrm{C}>\mathrm{T}$ polymorphisms and HIF- $1 \alpha$ expression has also been investigated. In breast cancer, HIF- $1 \alpha$ was over-expressed in $56.7 \%$ of the patients and the elevated level of HIF-1 $\alpha$ expression was associated with the T1772 polymorphic allele. The over-expression of HIF- $1 \alpha$ protein were found to be related to lymph node metastasis, histological grade and Ki-67 index[42]. In rectal cancer patients, HIF-1 $\alpha$ negative group had a much better the Overall survival (OS) and Recurrence-free survival 
(RFS) rates than that in HIF-1 $\alpha$-positive group. In addition, elevated HIF-1 $\alpha$ expression was significantly correlated with recurrence-free survival and metastasis-free survival rate in multivariate analysis [45]. In this study, we found that the HIF- $1 \alpha$ gene $1772 \mathrm{C}>\mathrm{T}$ polymorphisms showed statistically significant associations with PFS and OS by log-rank tests. The patients with CC had markedly longer PFS and OS than those carrying CT and TT genotype. The HIF-1 $\alpha$ expression level significantly related to the OS, but not the FPS. These results suggest the potential application of C1772T polymorphism and HIF- $1 \alpha$ expression in individualizing chemotherapy and predicting the clinical outcome of on NSCLC patients underwent chemotherapy.

Several limitations in this study need to be addressed. This study was a single-center cohort investigation on a relatively small scale, and thus, replication studies with larger scale cohorts are warranted. Secondly, we only enrolled Chinese patients in this study, so whether the positive association exists in other ethnic populations remains to be tested.

\section{Conflict of Interest}

None.

\section{Acknowledgements}

We thank Dr Xuwei Hou from University of Mississippi Medical Center for his help in statistic analyses with SAS software.

\section{References}

1 Chang A: Chemotherapy, chemoresistance and the changing treatment landscape for NSCLC. Lung Cancer 2011;71:3-10.

- Gautschi O, Hugli B, Ziegler A, Bigosch C, Bowers NL, Ratschiller D, Jermann M, Stahel RA, Heighway J, Betticher DC: Cyclin D1 (CCND1) A870G gene polymorphism modulates smoking-induced lung cancer risk and response to platinum-based chemotherapy in non-small cell lung cancer (NSCLC) patients. Lung Cancer 2006; 51:303-311.

3 Zhou C, Ren S, Zhou S, Zhang L, Su C, Zhang Z, Deng Q, Zhang J: Predictive effects of ERCC1 and XRCC3 SNP on efficacy of platinum-based chemotherapy in advanced NSCLC patients. Jpn J Clin Oncol 2010;40:954960.

- 4 Cui LH, Yu Z, Zhang TT, Shin MH, Kim HN, Choi JS: Influence of polymorphisms in MTHFR 677 C-->T, TYMS 3R-->2R and MTR 2756 A-->G on NSCLC risk and response to platinum-based chemotherapy in advanced NSCLC. Pharmacogenomics 2011;12:797-808.

-5 Wu J, Liu J, Zhou Y, Ying J, Zou H, Guo S, Wang L, Zhao N, Hu J, Lu D, Jin L, Li Q, Wang JC: Predictive value of XRCC1 gene polymorphisms on platinum-based chemotherapy in advanced non-small cell lung cancer patients: a systematic review and meta-analysis. Clin Cancer Res 2012;18:3972-3981.

-6 Butkiewicz D, Drosik A, Suwinski R, Krzesniak M, Rusin M, Kosarewicz A, Rachtan J, Matuszczyk I, Gawkowska-Suwinska M: Influence of DNA repair gene polymorphisms on prognosis in inoperable nonsmall cell lung cancer patients treated with radiotherapy and platinum-based chemotherapy. Int J Cancer 2012;131:E1100-1108.

7 Yan PW, Huang XE, Yan F, Xu L, Jiang Y: Influence of MDR1 gene codon 3435 polymorphisms on outcome of platinum-based chemotherapy for advanced non small cell lung cancer. Asian Pac J Cancer Prev 2011;12:2291-2294.

8 Shiraishi K, Kohno T, Tanai C, Goto Y, Kuchiba A, Yamamoto S, Tsuta K, Nokihara H, Yamamoto N, Sekine I, Ohe Y, Tamura T, Yokota J, Kunitoh H.: Association of DNA repair gene polymorphisms with response to platinum-based doublet chemotherapy in patients with non-small-cell lung cancer. J Clin Oncol 2010;28:4945-4952. 


\section{Cellular Physiology $\quad$ Cell Physiol Biochem 2013;32:1566-1576 and Biochemistry \\ Wu/Zhang/Liu/Zheng/Hu: HIF1 $\alpha$ and Chemotherapy Response in Advanced NSCLC}

-9 Vaupel P: Tumor microenvironmental physiology and its implications for radiation oncology. Semin Radiat Oncol 2004;14:198-206.

10 Chan DA, Giaccia AJ: Hypoxia, gene expression, and metastasis. Cancer Metastasis Rev 2007;26:333-339.

11 Chaudary N, Hill RP: Hypoxia and metastasis in breast cancer. Breast Dis 2006;26:55-64.

12 Krishnamachary B, Semenza GL: Analysis of hypoxia-inducible factor 1alpha expression and its effects on invasion and metastasis. Methods Enzymol 2007;435:347-354.

-13 Tsai YP, Wu KJ: Hypoxia-regulated target genes implicated in tumor metastasis. J Biomed Sci 2012;19:102.

14 Kobayashi M, Nakagawa K: [Metastasis and hypoxia-inducible factor]. Gan To Kagaku Ryoho 2010;37:20472051.

-15 Hou XW, Yang RQ Zhong YG, Gao W, Sun SP, Wang NF: G501C polymorphism of the oxidized LDL receptor gene is associated with albuminuria in Chinese essential hypertension patients. Genet Mol Res 2011;10: [Epub ahead of print].

16 Chun YS, Kim MS, Park JW: Oxygen-dependent and -independent regulation of HIF-1alpha. J Korean Med Sci 2002;17:581-588.

17 Fang J, Yan L, Shing Y, Moses MA: HIF-1alpha-mediated up-regulation of vascular endothelial growth factor, independent of basic fibroblast growth factor, is important in the switch to the angiogenic phenotype during early tumorigenesis. Cancer Res 2001;61:5731-5735.

18 Raheja LF, Genetos DC, Wong A, Yellowley CE: Hypoxic regulation of mesenchymal stem cell migration: the role of RhoA and HIF-1alpha. Cell Biol Int 2011;35:981-989.

19 Semenza GL: Hypoxia-inducible factors: mediators of cancer progression and targets for cancer therapy. Trends Pharmacol Sci 2012;33:207-214.

20 Monsef N, Soller M, Panagopoulos I, Abrahamsson PA: HIF1alpha isoforms in benign and malignant prostate tissue and their correlation to neuroendocrine differentiation. BMC Cancer 2010;10:385.

-21 Figlin RA, de Souza P, McDermott D, Dutcher JP, Berkenblit A, Thiele A, Krygowski M, Strahs A, Feingold J, Boni J, Hudes G.: Analysis of PTEN and HIF-1alpha and correlation with efficacy in patients with advanced renal cell carcinoma treated with temsirolimus versus interferon-alpha. Cancer 2009;115:3651-3660.

-22 Schrijvers ML, van der Laan BF, de Bock GH, Pattje WJ, Mastik MF, Menkema L, Langendijk JA, Kluin PM, Schuuring E, van der Wal JE: Overexpression of intrinsic hypoxia markers HIF1alpha and CA-IX predict for local recurrence in stage T1-T2 glottic laryngeal carcinoma treated with radiotherapy. Int J Radiat Oncol Biol Phys 2008;72:161-169.

23 Chen HH, Su WC, Lin PW, Guo HR, Lee WY: Hypoxia-inducible factor-1alpha correlates with MET and metastasis in node-negative breast cancer. Breast Cancer Res Treat 2007;103:167-175.

24 Sun L, Liu Y, Lin S, Shang J, Liu J, Li J, Yuan S, Zhang L: Early growth response gene-1 and hypoxia-inducible factor-1alpha affect tumor metastasis via regulation of tissue factor. Acta Oncol 2013;52:842-845.

25 Monti E, Gariboldi MB: HIF-1 as a target for cancer chemotherapy, chemosensitization and chemoprevention. Curr Mol Pharmacol 2011;4:62-77.

26 Semenza GL: Targeting HIF-1 for cancer therapy. Nat Rev Cancer 2003;3:721-732.

-27 Vainrib M, Golan M, Amir S, Dang DT, Dang LH, Bar-Shira A, Orr-Urtreger A, Matzkin H, Mabjeesh NJ: HIF1A C1772T polymorphism leads to HIF-1alpha mRNA overexpression in prostate cancer patients. Cancer Biol Ther 2012;13:720-726.

28 Li P, Cao Q, Shao PF, Cai HZ, Zhou H, Chen JW, Qin C, Zhang ZD, Ju XB, Yin CJ: Genetic polymorphisms in HIF1A are associated with prostate cancer risk in a Chinese population. Asian J Androl 2012;14:864-869.

29 Wang X, Cui E, Zeng H, Hua F, Wang B, Mao W, Feng X: RAGE genetic polymorphisms are associated with risk, chemotherapy response and prognosis in patients with advanced NSCLC. PLoS One 2012;7:e43734.

30 Goldstraw P, Crowley J, Chansky K, Giroux DJ, Groome PA, Rami-Porta R, Postmus PE, Rusch V, Sobin L: The IASLC Lung Cancer Staging Project: proposals for the revision of the TNM stage groupings in the forthcoming (seventh) edition of the TNM Classification of malignant tumours. J Thorac Oncol 2007;2:706714.

- 31 Wu W, Li H, Wang H, Zhao X, Gao Z, Qiao R, Zhang W, Qian J, Wang J, Chen H, Wei Q Han B, Lu D.: Effect of polymorphisms in XPD on clinical outcomes of platinum-based chemotherapy for Chinese non-small cell lung cancer patients. PLoS One 2012;7:e33200.

32 Santo A, Genestreti G, Terzi A, Azzoni P, Sava T, Manno P, Molino A, Pattaro C, Micciolo R, Cetto GL: Gemcitabine (GEM) and vindesine (VDS) in advanced non-small cell lung cancer (NSCLC): a phase II study in elderly or poor performance status patients. Lung Cancer 2006;53:355-360. 


\section{Cellular Physiology $\quad$ Cell Physiol Biochem 2013;32:1566-1576 and Biochemistry

-33 Niho S, Kubota K, Goto K, Yoh K, Ohmatsu H, Kakinuma R, Saijo N, Nishiwaki Y: First-line single agent treatment with gefitinib in patients with advanced non-small-cell lung cancer: a phase II study. J Clin Oncol 2006;24:64-69.

-34 Nava-Salazar S, Sanchez-Rodriguez EN, Mendoza-Rodriguez CA, Moran C, Romero-Arauz JF, Cerbon MA: Polymorphisms in the hypoxia-inducible factor 1 alpha gene in Mexican patients with preeclampsia: A case-control study. BMC Res Notes 2011;4:68.

- 35 Soini Y, Kahlos K, Puhakka A, Lakari E, Saily M, Paakko P, Kinnula V: Expression of inducible nitric oxide synthase in healthy pleura and in malignant mesothelioma. Br J Cancer 2000;83:880-886.

-36 Mera-Menendez F, Hinojar-Gutierrez A, Guijarro Rojas M, de Gregorio JG, Mera-Menendez E, Sanchez JJ, Quintanilla M, Cerezo L, Gamallo C: Polymorphisms in HIF-1alpha affect presence of lymph node metastasis and can influence tumor size in squamous-cell carcinoma of the glottic larynx. Clin Transl Oncol 2013;15:358-363.

- 37 Zagouri F, Sergentanis TN, Gazouli M, Tsigginou A, Dimitrakakis C, Papaspyrou I, Eleutherakis-Papaiakovou E, Chrysikos D, Theodoropoulos G, Zografos GC,Antsaklis A, Dimopoulos AM, Papadimitriou CA: HSP90, HSPA8, HIF-1 alpha and HSP70-2 polymorphisms in breast cancer: a case-control study. Mol Biol Rep 2012;39:10873-10879.

- 38 Li H, Bubley GJ, Balk SP, Gaziano JM, Pollak M, Stampfer MJ, Ma J: Hypoxia-inducible factor-1alpha (HIF1alpha) gene polymorphisms, circulating insulin-like growth factor binding protein (IGFBP)-3 levels and prostate cancer. Prostate 2007;67:1354-1361.

-39 Havelund BM, Spindler KL, Ploen J, Andersen RF, Jakobsen A: Single nucleotide polymorphisms in the HIF1alpha gene and chemoradiotherapy of locally advanced rectal cancer. Oncol Lett 2012;4:1056-1060.

-40 Hou XW, Son J, Wang Y, Ru YX, Lian Q Majiti W, Amazouzi A, Zhou YL, Wang PX, Han ZC: Granulocyte colonystimulating factor reduces cardiomyocyte apoptosis and improves cardiac function in adriamycin-induced cardiomyopathy in rats. Cardiovasc Drugs Ther 2006;20:85-91.

-41 Xu HY, Hou XW, Wang LF, Wang NF, Xu J: Association between transforming growth factor beta1 polymorphisms and left ventricle hypertrophy in essential hypertensive subjects. Mol Cell Biochem 2010;335:13-17.

42 Kim HO, Jo YH, Lee J, Lee SS, Yoon KS: The C1772T genetic polymorphism in human HIF-1alpha gene associates with expression of HIF-1alpha protein in breast cancer. Oncol Rep 2008;20:1181-1187.

-43 Kuo WH, Shih CM, Lin CW, Cheng WE, Chen SC, Chen W, Lee YL: Association of hypoxia inducible factor1alpha polymorphisms with susceptibility to non-small-cell lung cancer. Transl Res 2012;159:42-50.

-44 Wohlkoenig C, Leithner K, Deutsch A, Hrzenjak A, Olschewski A, Olschewski H: Hypoxia-induced cisplatin resistance is reversible and growth rate independent in lung cancer cells. Cancer Lett 2011;308:134-143.

-45 Shioya M, Takahashi T, Ishikawa H, Sakurai H, Ebara T, Suzuki Y, Saitoh J, Ohno T, Asao T, Kuwano H, Nakano T: Expression of hypoxia-inducible factor 1 alpha predicts clinical outcome after preoperative hyperthermochemoradiotherapy for locally advanced rectal cancer. J Radiat Res 2011;52:821-827. 